\title{
Mid-Pliocene climate modelled using the UK Hadley Centre Model: PlioMIP Experiments 1 and 2
}

\author{
F. J. Bragg ${ }^{1}$, D. J. Lunt ${ }^{1}$, and A. M. Haywood ${ }^{2}$ \\ ${ }^{1}$ BRIDGE, School of Geographical Sciences, University of Bristol, University Road, Bristol, BS8 1SS, UK \\ ${ }^{2}$ School of Earth and Environment, University of Leeds, Woodhouse Lane, Leeds, LS2 9JT, UK
}

Correspondence to: F. J. Bragg (fran.bragg@ @bristol.ac.uk)

Received: 13 March 2012 - Published in Geosci. Model Dev. Discuss.: 18 April 2012

Revised: 7 August 2012 - Accepted: 8 August 2012 - Published: 13 September 2012

\begin{abstract}
The Pliocene Model Intercomparison Project (PlioMIP) is a sub-project of the Paleoclimate Modelling Intercomparison Project (PMIP) whose objective is to compare predictions of the mid-Pliocene climate from the widest possible range of general circulation models. The mid-Pliocene (3.3-3.0 Ma) is the most recent sustained period of greater warmth and atmospheric carbon dioxide concentration than the pre-industrial times and as such has potential to inform predictions of our warming climate in the coming century. This paper describes the UK contribution to PlioMIP using the Hadley Centre Model both in atmosphere-only mode (HadAM3, PlioMIP Experiment 1) and atmosphereocean coupled mode (HadCM3, PlioMIP Experiment 2). The coupled model predicts a greater overall warming $\left(3.3^{\circ} \mathrm{C}\right)$ relative to the control than the atmosphere-only $\left(2.5^{\circ} \mathrm{C}\right)$. The Northern Hemisphere latitudinal temperature gradient is greater in the coupled model with a warmer Equator and colder Arctic than the atmosphere-only model, which is constrained by sea surface temperatures from Pliocene proxy reconstructions. The atmosphere-only model predicts a reduction in equatorial precipitation and south Asian monsoon intensity, whereas the coupled model shows an increase in the intensity of these systems. We present sensitivity studies using alternative boundary conditions for both the Pliocene and the control simulations, indicating the sensitivity of the midPliocene warming to uncertainties in both pre-industrial and mid-Pliocene climate.
\end{abstract}

\section{Introduction}

This paper describes the Pliocene Model Intercomparison Project (PlioMIP) simulations carried out using the UK Meteorological Office Hadley Centre Model (HadAM3 and HadCM3).

General circulation models (GCMs) are one of the main tools used for studying the climate system of the present day and the past and to predict likely climate changes that can be expected in the future. These models vary significantly in the way they parameterise certain complex processes and as such vary in their simulation of the modern climate as well as in their past and future predictions. The Paleoclimate Modelling Project (PMIP, see http://pmip3.lsce.ipsl.fr/) exists to create intercomparisons of the widest possible range of models forced as nearly as possible with identical palaeo boundary conditions. The intercomparisons focus on different time slices of particular interest to the scientific community, including the Last Glacial Maximum (21 kyr), Last Interglacial (130 kyr, $125 \mathrm{kyr}$ and $115 \mathrm{kyr}$ ) and Mid-Holocene (6 kyr) and more recently extended to $8.2 \mathrm{kyr}$ and Pliocene, specifically the mid-Pliocene warm period (MPWP) from 3.29-2.97 Ma (Haywood et al., 2010).

The Pliocene is of particular interest for the development of the GCMs used in future climate predictions as it is the most recent sustained period that is significantly warmer than the present day and thus the climate system may operate in a similar manner to potential climates of the coming century. A substantial dataset describing the MPWP time slab has been assembled by the US Geological Survey PRISM project (Pliocene Research, Interpretation and Synoptic Mapping, http://geology.er.usgs.gov/eespteam/prism/), 
Control

Expts 1 \& 2
Pliocene

Expt 1

\section{Pliocene Expt 2}
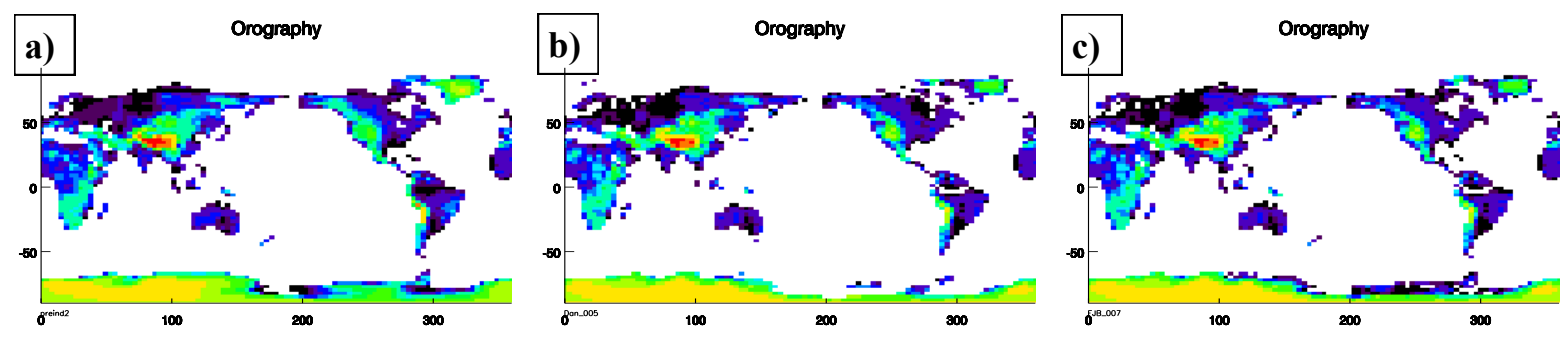

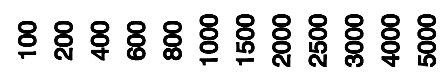
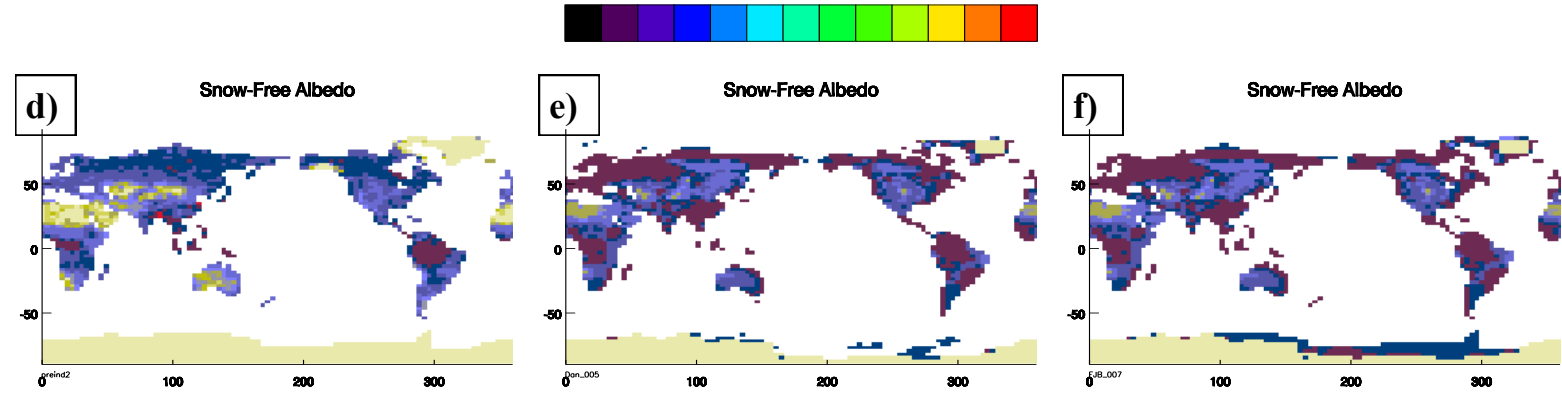

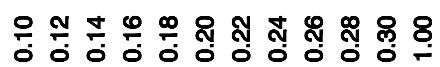

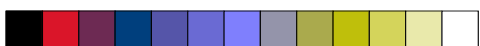

Fig. 1. Summary of land surface boundary conditions for PlioMIP simulations: panels (a)-(c) show orography projected onto the appropriate land-sea mask for control, Experiment 1 and Experiment 2 Pliocene simulations. Panels (d)-(f) show snow-free albedo for control, Experiment 1 and Experiment 2 Pliocene simulations - values above 0.3 shown in beige represent ice sheets.

including topography data, sea surface temperatures, vegetation reconstruction and ice sheet extents and topography (Dowsett et al., 2010). These data are used to force the models to achieve consistent simulations of how the Pliocene climate differs from the pre-industrial control.

This paper describes the implementation of the PRISM3 boundary conditions for use with the UK Hadley Centre Model according to the PlioMIP protocols for atmosphereonly models: "Experiment 1" (Haywood et al., 2010), and coupled ocean-atmosphere models: "Experiment 2" (Haywood et al., 2011). We also provide a summary of the basic results and some initial analysis including model-data comparison.

\section{Model description}

We use the UK Meteorological Office Hadley Centre Model, also known as the Unified Model (UM) for these experiments, specifically the atmosphere-only version, HadAM3 (Pope et al., 2000), for Experiment 1 and the coupled oceanatmosphere version, HadCM3 (Gordon et al., 2000), for Experiment 2 .

\subsection{Atmosphere}

The atmosphere module has a resolution of $96 \times 73$ grid points $\left(3.75^{\circ} \times 2.5^{\circ}\right)$ and 19 vertical levels using a hybrid $\sigma$-pressure grid with a timestep of $0.5 \mathrm{~h}$. An Arakawa B-grid (Arakawa and Lamb, 1977) is used in the horizontal plane to improve accuracy, with thermodynamic variables stored at the centre of the grid and wind components at the corners (Johns et al., 1997).

The atmosphere-only model specifies 12 mid-monthly fields of sea surface temperature as boundary conditions, which are interpolated to daily values at run-time.

A convection scheme developed by Gregory et al. (1997) is included which accounts for the direct effects of convection on momentum. A first order scheme for turbulent vertical mixing of momentum and thermodynamic quantities is used within the boundary layer, which can occupy up to the first 5 layers of the model (Smith, 1990). Sub grid-scale gravity wave and orographic drag parameterisations include the impact of orographic variance anisotropy (Milton and Wilson, 1996; Gregory et al., 1998).

Clouds are modelled as either water, ice or mixed-phase between 0 and $-9^{\circ} \mathrm{C}$. Clouds are aggregated into 3 layers 
Table 1. Summary of boundary conditions for PlioMIP simulations.

\begin{tabular}{|c|c|c|c|c|c|c|}
\hline & \multicolumn{3}{|c|}{ EXPT 1} & \multicolumn{3}{|c|}{ EXPT 2} \\
\hline & Pliocene & Control & BAS Modern & Pliocene & Control & PRISM2 \\
\hline Land-sea mask & $\begin{array}{l}\text { PlioMIP } \\
\text { preferred }\end{array}$ & UM standard & UM standard & UM standard & UM standard & UM standard \\
\hline $\begin{array}{l}\text { Topography including } \\
\text { ice sheets }\end{array}$ & $\begin{array}{l}\text { PlioMIP } \\
\text { anomaly } \\
\text { method }\end{array}$ & UM standard & UM standard & $\begin{array}{l}\text { PlioMIP } \\
\text { anomaly } \\
\text { method }\end{array}$ & UM standard & $\begin{array}{l}\text { PRISM2 } \\
\text { absolute }\end{array}$ \\
\hline $\begin{array}{l}\text { Land-surface properties } \\
\text { including ice }\end{array}$ & $\begin{array}{l}\text { PlioMIP } \\
\text { BIOME4 } \\
\text { vegetation }\end{array}$ & UM standard & $\begin{array}{l}\text { BAS-Observ } \\
\text { modern } \\
\text { vegetation }\end{array}$ & $\begin{array}{l}\text { PlioMIP } \\
\text { BIOME4 } \\
\text { vegetation }\end{array}$ & UM standard & $\begin{array}{l}\text { PRISM2 } \\
\text { vegetation }\end{array}$ \\
\hline Soils & UM standard & UM standard & UM standard & UM standard & UM standard & UM standard \\
\hline River routing & $\mathrm{n} / \mathrm{a}$ & $\mathrm{n} / \mathrm{a}$ & $\mathrm{n} / \mathrm{a}$ & UM standard & UM standard & UM standard \\
\hline SST & $\begin{array}{l}\text { PlioMIP } \\
\text { anomaly } \\
\text { method }\end{array}$ & UM standard & UM standard & $\mathrm{n} / \mathrm{a}$ & $\mathrm{n} / \mathrm{a}$ & $\mathrm{n} / \mathrm{a}$ \\
\hline Bathymetry & $\mathrm{n} / \mathrm{a}$ & $\mathrm{n} / \mathrm{a}$ & $\mathrm{n} / \mathrm{a}$ & UM standard & UM standard & UM standard \\
\hline $\begin{array}{l}\text { Solar constant } \\
\left(\mathrm{W} \mathrm{m}^{-2}\right)\end{array}$ & 1365 & 1365 & 1365 & 1365 & 1365 & 1365 \\
\hline $\begin{array}{l}\text { Sine obliquity } \\
\text { (angle) }\end{array}$ & $\begin{array}{l}0.397789 \\
\left(23.440^{\circ}\right)\end{array}$ & $\begin{array}{l}0.397789 \\
\left(23.440^{\circ}\right)\end{array}$ & $\begin{array}{l}0.397789 \\
\left(23.440^{\circ}\right)\end{array}$ & $\begin{array}{l}0.397789 \\
\left(23.440^{\circ}\right)\end{array}$ & $\begin{array}{l}0.397789 \\
\left(23.440^{\circ}\right)\end{array}$ & $\begin{array}{l}0.397789 \\
\left(23.440^{\circ}\right)\end{array}$ \\
\hline Eccentricity & 0.0167 & 0.0167 & 0.0167 & 0.0167 & 0.0167 & 0.0167 \\
\hline Perihelion (day/360) & 2.5 & 2.5 & 2.5 & 2.5 & 2.5 & 2.5 \\
\hline $\mathrm{CO}_{2}(\mathrm{ppm})$ & 405 & 280 & 280 & 405 & 280 & 401 \\
\hline $\mathrm{N}_{2} \mathrm{O}(\mathrm{ppb})$ & 269 & 269 & 269 & 269 & 269 & 269 \\
\hline $\mathrm{CH}_{4}(\mathrm{ppb})$ & 761 & 761 & 761 & 761 & 761 & 761 \\
\hline Ozone & $\begin{array}{l}\text { standard UM } \\
\text { climatology }\end{array}$ & $\begin{array}{l}\text { standard UM } \\
\text { climatology }\end{array}$ & $\begin{array}{l}\text { standard UM } \\
\text { climatology }\end{array}$ & $\begin{array}{l}\text { standard UM } \\
\text { climatology }\end{array}$ & $\begin{array}{l}\text { standard UM } \\
\text { climatology }\end{array}$ & $\begin{array}{l}\text { standard UM } \\
\text { climatology }\end{array}$ \\
\hline $\begin{array}{l}\text { Integration length } \\
\text { (years) }\end{array}$ & 50 & 50 & 50 & 500 & 200 & 200 \\
\hline Climatological means & 30 & 30 & 30 & 50 & 50 & 30 \\
\hline
\end{tabular}

(low, medium and high) and form when the cell moisture level standard deviation exceeds a critical level of relative humidity, $\mathrm{RH}_{\text {crit }}=0.7$. The threshold of total water content for precipitation to occur is varied between land and ocean cells to account for the different levels of available cloud condensation nuclei.

\subsection{Radiation and land-surface energy schemes}

The radiation scheme of Edwards and Slingo (1996) has 6 shortwave and 8 longwave bands and represents the effects of water vapour, carbon dioxide, ozone and minor trace gases. A background aerosol climatology following Cusack et al. (1998) increases the atmospheric absorption of shortwave radiation relative to previous versions, representing a significant improvement. The land-surface energy scheme, MOSES I (Cox et al., 1999) accounts for the effects of freezing and melting of soil moisture in 4 soil layers and includes the impact of atmospheric concentration of carbon dioxide, water vapour and temperature on stomatal resistance to evapotranspiration.

\subsection{Ocean}

The ocean module has a horizontal resolution of $288 \times 144$ grid points $\left(1.25^{\circ} \times 1.25^{\circ}\right)$ : that is, 6 ocean cells correspond to each atmosphere cell. The land-sea mask is defined at the atmosphere resolution to simplify coupling. There are 20 vertical levels with finer definition at the ocean surface: the first cell is $10 \mathrm{~m}$ deep. The ocean timestep is $1 \mathrm{~h}$. The ocean and atmosphere modules are coupled once a day with no flux adjustment being necessary.

Modern bathymetry is derived from the ETOPO5 reconstruction (Edwards, 1989) using a simple smoothing algorithm. Behaviour in some significant channels is modified from the resulting coarse interpolation to ensure a more realistic model performance (Gordon et al., 2000). The Greenland-Scotland ridge and Denmark Strait have 


\section{Control} Expt 1
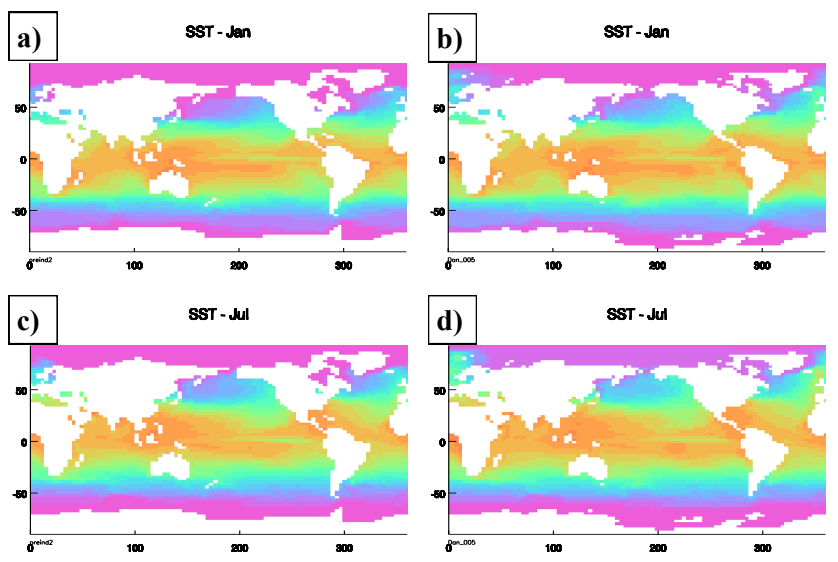

○ก+

L

Fig. 2. Summary of sea surface temperature boundary conditions for atmosphere-only PlioMIP simulations: panels (a)-(b) show January temperatures for control and Pliocene, panels (c)-(d) show July temperatures for control and Pliocene.

significant sub-gridscale channels which are lost in the smoothing and therefore have been recreated by deepening single-cell width channels in 3 locations along the ridge to reproduce a mean outflow matching observation. The resolution of the Gibraltar Strait leaves the Mediterranean isolated, so a partial mixing of the closest cells at each depth down to $1200 \mathrm{~m}$ is carried out to represent the actual mixing that occurs across this opening. The region around Indonesia is modified to ensure that flow occurs between Indonesia and Papua New Guinea and not between Indonesia and the mainland of Asia.

A rigid lid approach is used meaning there is no variation in volume of the ocean. Freshwater flux from land runoff is therefore converted to a salinity flux on entering the ocean. Ice sheets are not modelled dynamically in HadCM3, therefore, the snow accumulation on each ice sheet is balanced by a notional equivalent loss through iceberg calving represented as a freshwater flux distributed around the edge of the ice sheet and polar oceans.

The ocean mixed layer mixing of tracers (potential temperature and salinity) is represented by the Kraus and Turner (1967) model which assigns $15 \%$ of gravitational potential energy and $70 \%$ of wind-stress energy to turbulent kinetic energy, which is mixed out exponentially with depth. At all depths, 5 iterations of convective mixing of tracers are carried out each timestep. Horizontal mixing of tracers is carried out using the isopycnal parameterisation of Gent and McWilliams (1990). Horizontal mixing of momentum is performed using a latitudinally varying formulation which, coupled with the finer resolution of the ocean grid, enables western boundary currents to be resolved.

\subsection{Sea ice}

Sea ice is calculated as a zero layer model on top of the ocean grid. Partial cell coverage of sea ice is possible in all high latitude cells, up to 0.995 in the Arctic and 0.98 in the Antarctic according to the parameterisation of sea ice concentration of Hibler (1979). Ice forms primarily by freezing in leads. Ice can also form from snow falling on existing ice and by freezing at the base at the freezing point of $-1.8^{\circ} \mathrm{C}$. A constant salinity is assumed for ice, with excess salt from freezing being rejected into the ocean. Ice drift follows the ocean currents in the top layer, but converging ice is limited to $4 \mathrm{~m}$ in depth. Ice albedo is set at 0.8 below $-10^{\circ} \mathrm{C}$ and 0.5 above $0{ }^{\circ} \mathrm{C}$ with a linear variation between.

\subsection{Model validation}

The Hadley Centre model validation is documented for HadAM3 in Pope et al. (2000) and for HadCM3 in Gordon et al. (2000). The model has been shown to reproduce the main features of modern climate observations.

\section{Experimental design}

Table 1 summarises the experimental design for both Experiment 1 (Haywood et al., 2010) and Experiment 2 (Haywood et al., 2011) Pliocene and control simulations. Also included are details for an additional fully coupled Pliocene simulation, an experiment based on the previous PRISM2 version of boundary conditions (Dowsett, 2007) which will be referred to in the discussion below.

\subsection{Land-sea mask}

The PlioMIP protocols define two possible land-sea masks: a "preferred" mask which differs from modern (primarily due to sea-level change and glacial erosion) and an "alternate" mask which is the same as modern. For the Pliocene Experiment 1 simulation, the "preferred" PlioMIP $2^{\circ} \times 2^{\circ}$ fractional land-sea mask was interpolated onto the UM $3.75^{\circ} \times 2.5^{\circ}$ grid, then the output cells with a land fraction greater than 0.5 were set to be land cells. The principal differences from the modern mask are in the Hudson Bay, which is filled in at low altitude, and the regions of West Antarctica where the modern ice shelf is absent in the Pliocene. The Panama Seaway is post-edited to be closed as the interpolation process renders this region as ocean in the coarser grid. The standard UM land-sea mask was used for the control run. All of the coupled Experiment 2 simulations also use the standard UM land-sea mask without modification due to the difficulty of changing the land-sea mask in the ocean module 

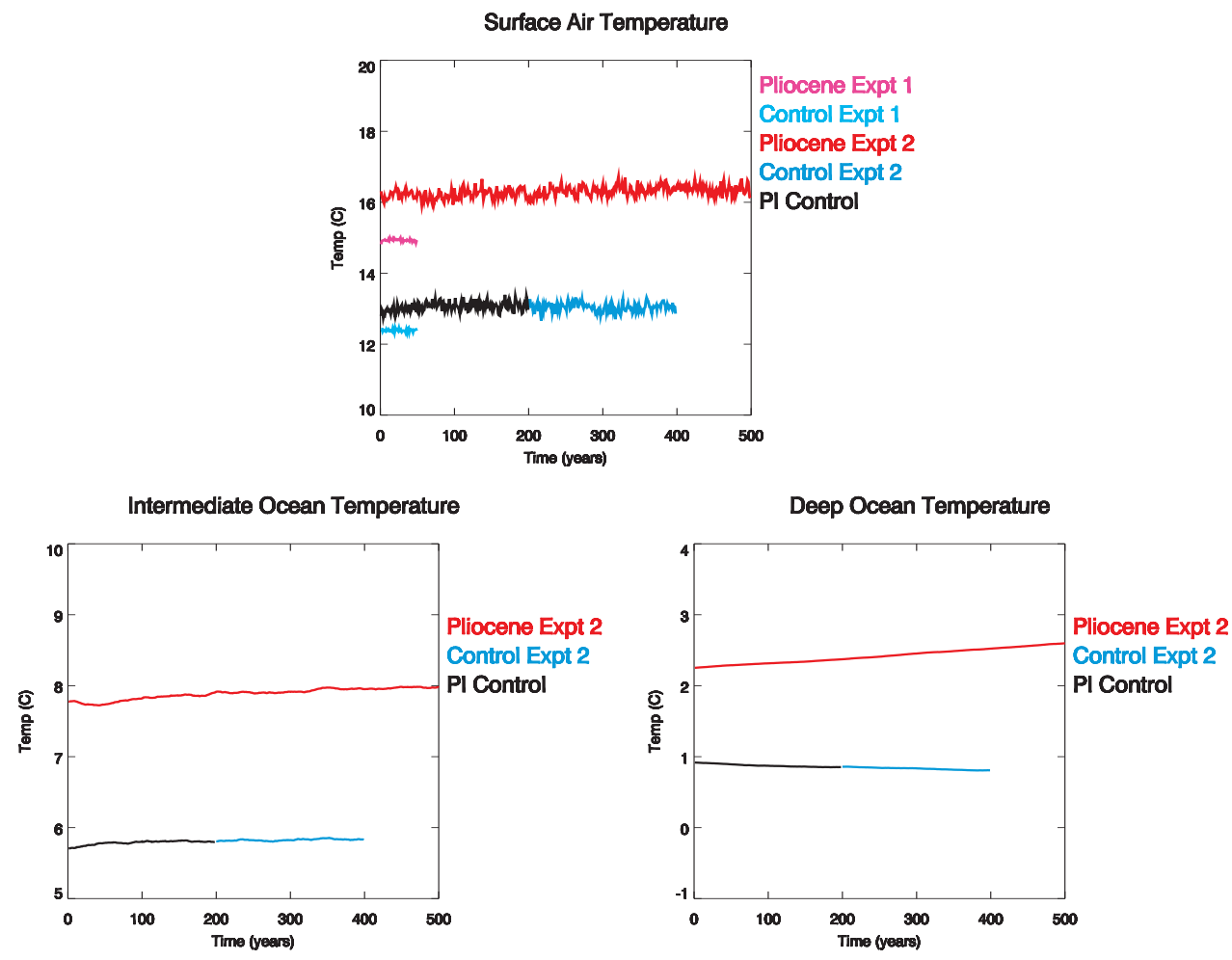

Fig. 3. Time series of global mean temperatures.

and achieving a stable solution. This mask is derived from the US Navy $10^{\prime}$ topography (NCAR/Navy, 1984) and can be seen in the boundary condition plots in Fig. 1.

\subsection{Topography including ice sheets}

For both experiments, Pliocene topography was created using the anomaly method specified in the PlioMIP protocol. Anomalies were calculated as the difference between the PlioMIP Pliocene and control datasets. For Experiment 1, the UM standard topography was then extended to cover the different land-sea masks using an iterative expansion algorithm before applying the anomaly values. Ice sheet topography is included simply as part of the overall topography. The resultant field was then masked with the required final land-sea mask ensuring that all ocean points have an elevation of $0 \mathrm{~m}$ and no land points are below sea-level. For the pre-industrial control dataset, calculation of derived fields required for the model, describing the orographic variance, was performed on the high resolution topography data prior to regridding onto the UM resolution. These data were also used for the Pliocene in both experiments as topographic data on the same resolution as the modern data are not available to make the equivalent variance calculations. In the case of Experiment 1, the data were expanded to match the preferred land-sea mask.

\subsection{Land surface properties including ice sheet extent}

Properties required by the land surface energy scheme for the Pliocene simulations were derived from the PlioMIP BIOME4 dataset by means of the lookup table of Haywood et al. (2010). This table relates the 28 biome types describing land cover to the MOSES I input parameters (Cox et al., 1999) via the land-use classifications of Wilson and Henderson-Sellers (1985). These data include ice as a possible surface type, hence the extent of ice sheets is naturally incorporated into this process. In land regions which are specified as ocean in the PlioMIP dataset, these derived parameter fields were expanded out from neighbouring land points, most notably in the West Antarctic region. This conversion is illustrated using snow-free albedo which is shown in Fig. 1.

For the control experiments, the standard UM dataset of vegetation was applied which is based on the Wilson and Henderson-Sellers (1985) archive of land cover.

\subsection{Soil properties}

Soil properties in both Pliocene and control experiments are those used in the standard UM setup derived from Wilson and Henderson-Sellers (1985), expanded in the case of Experiment 1 Pliocene simulation to match the preferred landsea mask. In reality, soil properties could be different at the Pliocene compared to modern, but a lack of Pliocene 

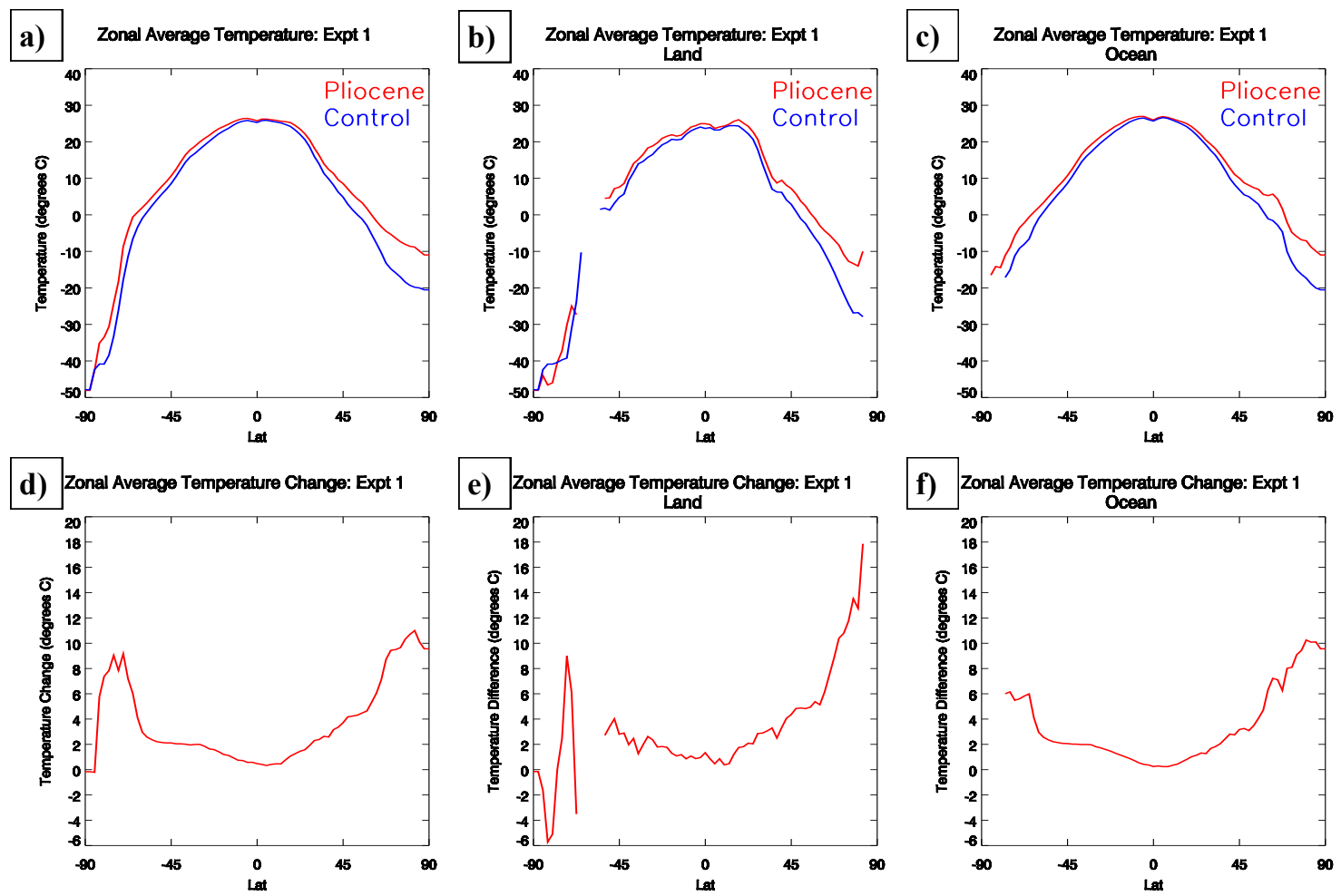

Fig. 4. Summary of zonal mean of predicted surface air temperatures for Experiment 1: panels (a)-(c) show absolute values for Pliocene (red) and control (blue) for global, land and ocean means, respectively. Panels (d)-(f) show the corresponding differences in temperature between the 2 simulations.

palaeosol data precludes meaningful changes to be implemented in the model.

\subsection{River routing (Experiment 2 only)}

River routing in both Pliocene and control experiments is the same as the UM standard catchments.

\subsection{Sea surface temperatures and sea ice (Experiment 1 only)}

Sea surface temperatures (SST) for the Pliocene simulation were created using the specified PlioMIP anomaly method of Haywood et al. (2010), Sect. 2.2. The difference between the Pliocene and modern fields was calculated and applied to the UM standard SST climatology for each month. Temperatures were not allowed to fall below $-1.7^{\circ} \mathrm{C}$. The data were expanded into regions which are land in the standard UM mask using an iterative process, in particular into the Hudson Bay. The SST fields for January and July are shown in Fig. 2.

Sea ice is specified on a monthly basis where SST $<-1.7^{\circ} \mathrm{C}$ with a depth of $2 \mathrm{~m}$ in the Northern Hemisphere and $1 \mathrm{~m}$ in the Southern Hemisphere, as in the control.

\subsection{Solar constant and orbital parameters}

The solar constant and orbital parameters were unchanged from the standard UM values (Ingram et al., 1997) and are summarised in Table 1. The perihelion is specified as day 2.5 from a 360 day year giving an angle of $281.5^{\circ}$ from the spring equinox.

\subsection{Trace gases and aerosols}

The atmospheric $\mathrm{CO}_{2}$ concentration was set to $280 \mathrm{ppmv}$ for the control simulations and $405 \mathrm{ppmv}$ for the Pliocene in accordance with the PlioMIP protocol. Levels of methane (761 ppb) and nitrous oxide (269 ppb) were held constant in all simulations at standard pre-industrial levels. Ozone is specified as a fixed annual climatology of 12 monthly fields which is the same for all simulations. No aerosols are specified other than the background climatology of the scheme of Cusack et al. (1998).

\subsection{Initialisation}

For Experiment 1 simulations, the atmosphere was initialised using a standard UM pre-industrial restart file. For Experiment 2 , the atmosphere and ocean modules were initialised from the respective Pliocene and control simulations based 
Table 2. Summary of overall global means and differences from control for Experiments 1 and 2.

\begin{tabular}{|c|c|c|c|c|}
\hline & \multicolumn{2}{|c|}{ Expt 1} & \multicolumn{2}{|c|}{ Expt 2} \\
\hline & Absolute Pliocene & Absolute control & Absolute Pliocene & Absolute control \\
\hline TOA global energy imbalance $\left(\mathrm{W} \mathrm{m}^{-2}\right)$ & 6.01 & 1.50 & 0.22 & -0.12 \\
\hline & Absolute Pliocene & Delta (Plio-control) & Absolute Pliocene & Delta (Plio-control) \\
\hline Global mean annual surface air temp $\left({ }^{\circ} \mathrm{C}\right)$ & 14.93 & 2.53 & 16.34 & 3.27 \\
\hline $\begin{array}{l}\text { Global mean total precipitation rate } \\
\left(\mathrm{mm} \mathrm{day}^{-1}\right)\end{array}$ & 2.94 & 0.12 & 3.05 & 0.17 \\
\hline
\end{tabular}

Table 3. Summary of polar amplification data (all temperatures in ${ }^{\circ} \mathrm{C}$ ) for Experiments 1 and 2: Columns South Pole - averaged over latitudes $<60^{\circ} \mathrm{S}$; North Pole - averaged over latitudes $>60^{\circ} \mathrm{N}$; Equator - averaged over latitudes between $30^{\circ} \mathrm{N}$ and $30^{\circ} \mathrm{S}$. Polar amplification is defined as difference between polar and equatorial Pliocene-Control change.

\begin{tabular}{lrrrrrrrr}
\hline & \multicolumn{3}{c}{ Expt 1 } & & \multicolumn{3}{c}{ Expt 2 } \\
\cline { 2 - 3 } \cline { 6 - 7 } & South Pole & Equator & North Pole & & South Pole & Equator & North Pole \\
\hline Pliocene mean & -11.53 & 24.25 & -4.62 & & -12.63 & 26.52 & -5.68 \\
Control mean & -17.60 & 23.18 & -12.81 & & -18.61 & 23.96 & -11.89 \\
Pliocene-Control change & 6.08 & 1.07 & 8.20 & & 5.98 & 2.56 & 6.21 \\
Polar Amplification & 5.01 & & 7.13 & & 3.42 & & 3.65 \\
Pliocene latitudinal gradient & 35.77 & & 28.87 & & 39.15 & & 32.20 \\
Control latitudinal gradient & 40.79 & & 35.99 & & 42.57 & & 35.85 \\
\hline
\end{tabular}

on PRISM2 boundary conditions (Lunt et al., 2010) with cumulative integration lengths of over $1000 \mathrm{yr}$. Time series of temperature evolutions of the global mean of $1.5 \mathrm{~m}$ air temperature are shown in Fig. 3 along with intermediate and deep ocean temperature evolution for the coupled simulations.

Other parameters were initialised as follows:

- For coupled experiments, sea ice is initialised using the method of Sect. 3.6.

- Soil temperature is initialised with a constant value of $14^{\circ} \mathrm{C}$ in ice free regions and $-6^{\circ} \mathrm{C}$ with ice cover.

- Soil moisture is initialised with constant default values for each of the 4 layers.

- Snow depth is initialised with a flat profile of $50 \mathrm{~m}$ over ice and none elsewhere.

\subsection{Integration length, spinup and climatological means}

Both Experiment 1 simulations were run for $50 \mathrm{yr}$, as required by the PlioMIP protocol, enabling the simulations to come to equilibrium. The Experiment 2 Pliocene simulation was run for $500 \mathrm{yr}$ as specified in the protocol. The control model was run for $200 \mathrm{yr}$, but this simulation is a continuation from that of Lunt et al. (2010) and has a cumulative integration length of $1238 \mathrm{yr}$ with no change to the boundary conditions.
Average climatologies for the Experiment 1 simulations were calculated over the last $30 \mathrm{yr}$ and for Experiment 2 over the final $50 \mathrm{yr}$.

\section{Results}

The results are presented here firstly for Experiment 1, then Experiment 2.

\subsection{Global}

Global means for the Experiment 1 and 2 simulations are listed in Table 2. The coupled model predicts a significantly greater level of warming in the Pliocene relative to the control than the atmosphere-only version: $3.3^{\circ} \mathrm{C}$ compared with $2.5^{\circ} \mathrm{C}$. There is also a small rise in total precipitation in the Pliocene relative to the control of around $4 \%$ in Experiment 1 and $5.5 \%$ in Experiment 2.

\subsection{Experiment 1}

Figure 4 shows the zonal average surface air temperatures for Experiment 1, for land only and ocean only, both absolute values and Pliocene minus control difference. Table 3 shows the mean temperatures averaged over the two polar regions (latitudes higher than 60 degrees) and the equatorial area between $30^{\circ} \mathrm{N}$ and $30^{\circ} \mathrm{S}$, including values for polar amplification taken as the differences between these means. The 

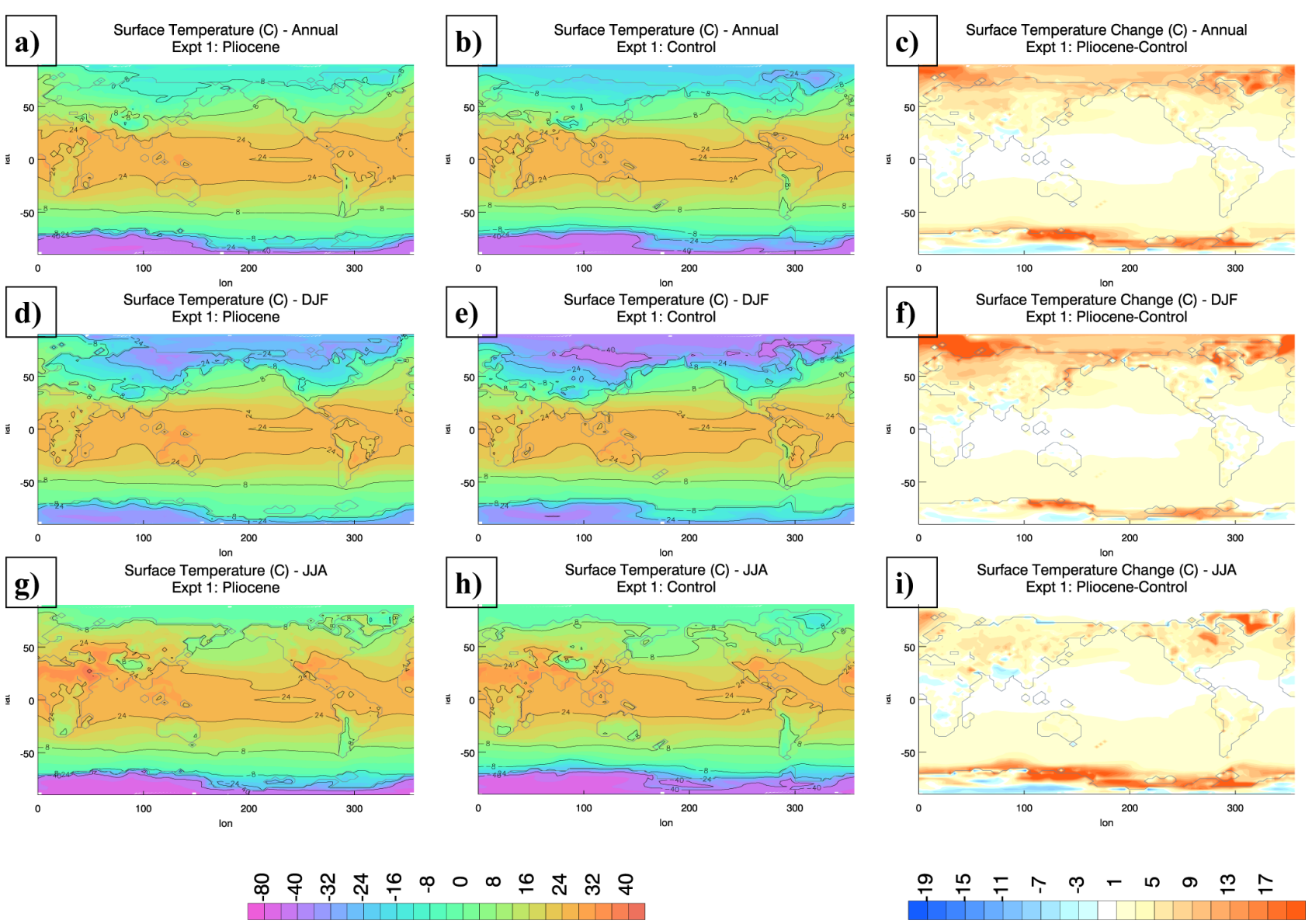

Fig. 5. Summary of surface air temperatures for Experiment 1: panels (a)-(c) show annual mean temperatures for Pliocene and control simulations and the difference between them. Panels (d)-(f) similarly show the DJF means and panels (g)-(i) the JJA means.

difference profile (Fig. 4d) over the non-polar oceans falls almost to $0^{\circ} \mathrm{C}$ around the Equator with a mean value across the tropics of around $1{ }^{\circ} \mathrm{C}$; this profile is strongly constrained by the imposed sea surface temperature boundary condition. The latitudinal temperature gradient, especially in the Northern Hemisphere is significantly reduced in the Pliocene relative to the control (Fig. 4a-c). Polar amplification in the Pliocene relative to the control is clear in the zonal profiles with mean values of around $5^{\circ} \mathrm{C}$ in the Southern Hemisphere and $7^{\circ} \mathrm{C}$ in the Northern Hemisphere.

These results are apparent in greater detail in Fig. 5 which shows annual, DJF and JJA mean surface air temperature patterns for both Pliocene and control simulations and the difference between them. The polar amplification is most pronounced in winter for both hemispheres. In the Antarctic, the majority of the warming maxima occur in regions which are ocean in the Pliocene and land in the control simulation due to the change in albedo and heat capacity, combined with smaller areas on land where the ice sheet is at considerably lower altitude in the Pliocene model. Pliocene Arctic warming is also associated with regions of change in the altitude or extent of the Greenland icesheet in a similar manner to the Antarctic. There is also a warming evident in the North Atlantic driven by the sea surface temperature boundary conditions which are significantly warmer than in the control.

Figure 6 summarises the precipitation patterns for the Pliocene and control experiments and the difference between them, showing the annual, DJF and JJA means. There is a reduction in equatorial rainfall in the Pliocene, especially in the extent and intensity of the south Asian summer monsoon systems.

\subsection{Experiment 2}

Figure 7 shows the zonal mean surface air temperatures globally, for land only and ocean only along with Pliocene minus control difference for Experiment 2. Mean polar and equatorial temperatures and polar amplification values are listed in Table 3 as for Experiment 1 (Sect. 4.2). Experiment 2 shows more warming globally than Experiment $1\left(3.3^{\circ} \mathrm{C}\right.$ compared with $2.5^{\circ} \mathrm{C}$, see Table 2) but this temperature increase is more evenly distributed latitudinally, with $2.5^{\circ} \mathrm{C}$ warming in the equatorial zone and reduced polar amplification in both hemispheres of $3.5^{\circ} \mathrm{C}$. These results are shown 

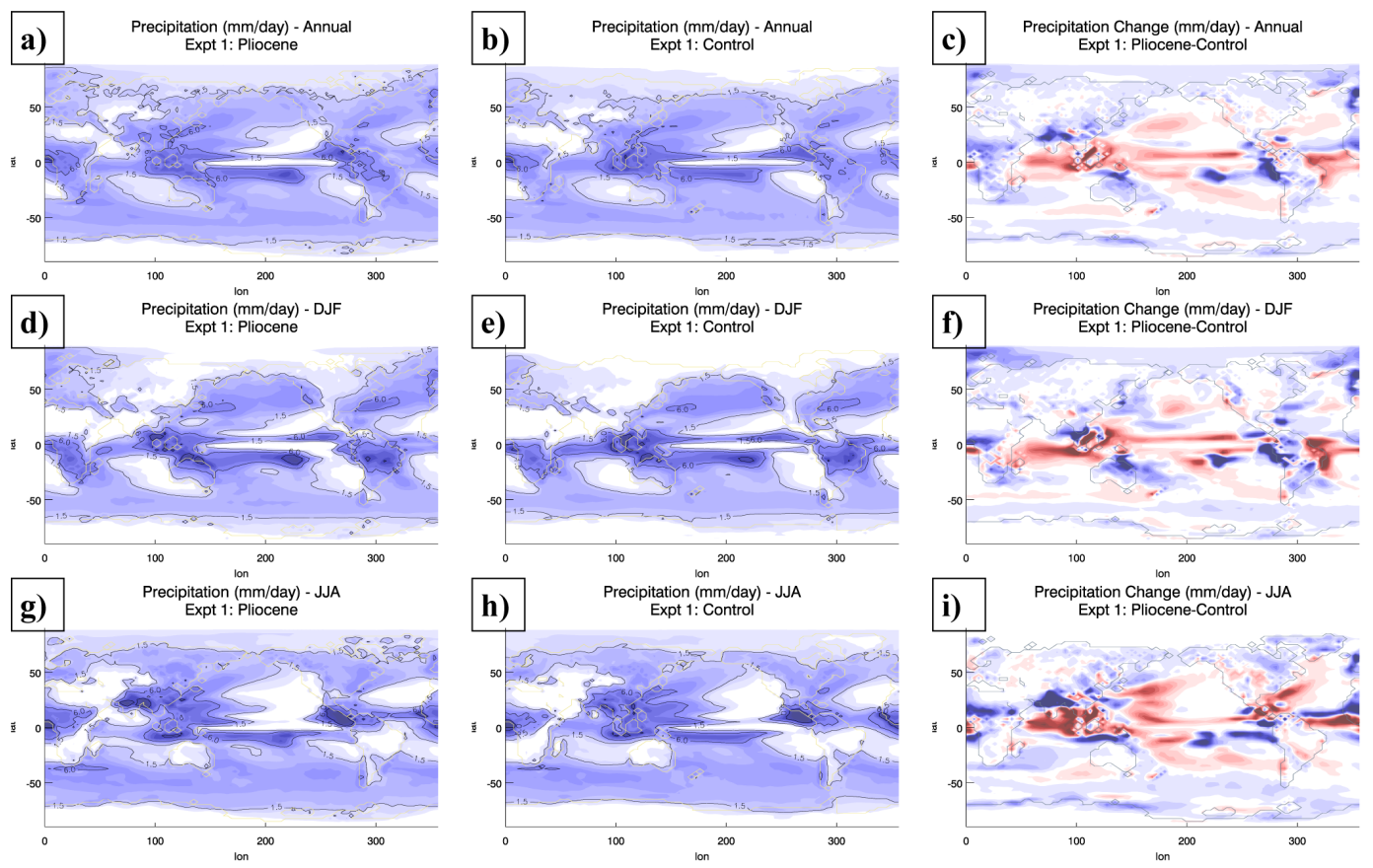

绐

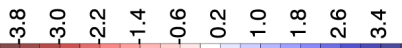

Fig. 6. Summary of mean precipitation $\left(\mathrm{mm} \mathrm{day}^{-1}\right)$ for Experiment 1: panels (a)-(c) show annual mean precipitation for Pliocene and control simulations and the difference between them. Panels (d)-(f) similarly show the DJF means and panels (g)-(i) the JJA means.

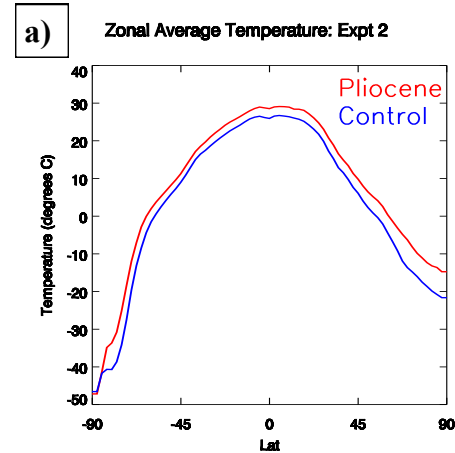

d) Zonal Average Temperature Change: Expt 2

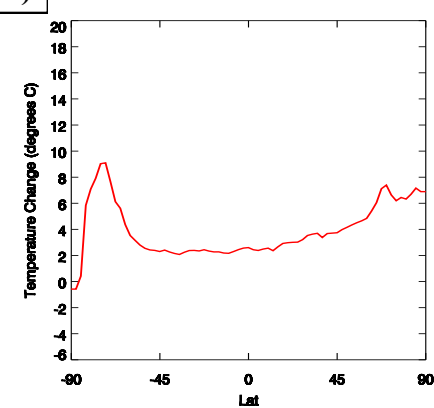

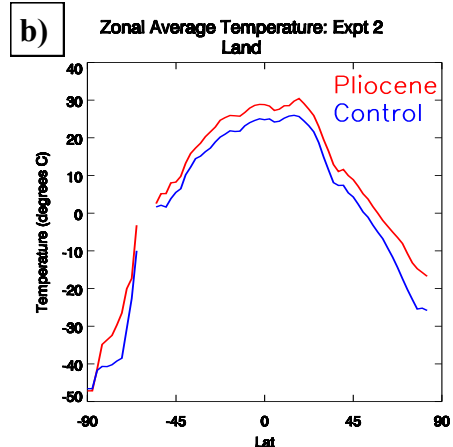

e)

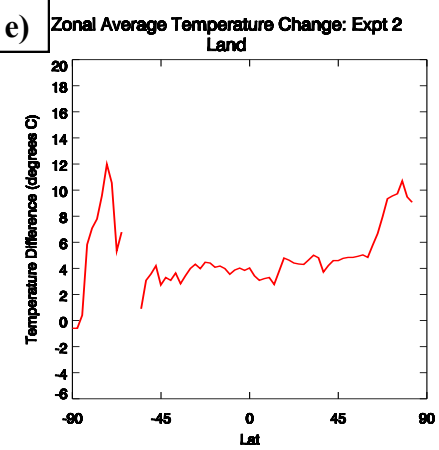

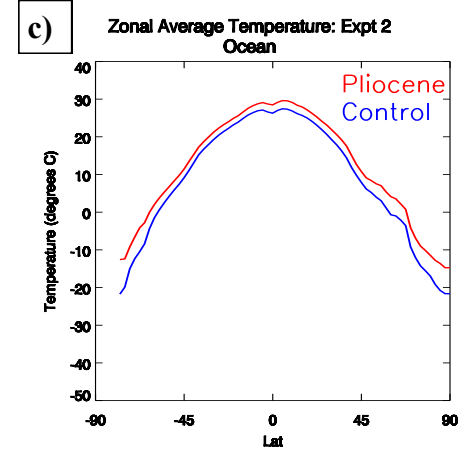

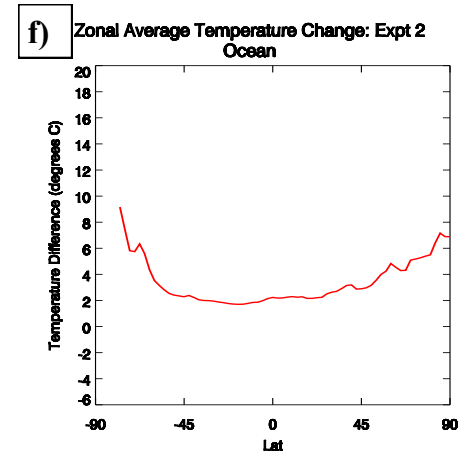

Fig. 7. Summary of zonal mean of predicted surface air temperatures for Experiment 2: panels (a)-(c) show absolute values for Pliocene (red) and control (blue) for global, land and ocean means, respectively. Panels (d)-(f) show the corresponding differences in temperature between the 2 simulations. 

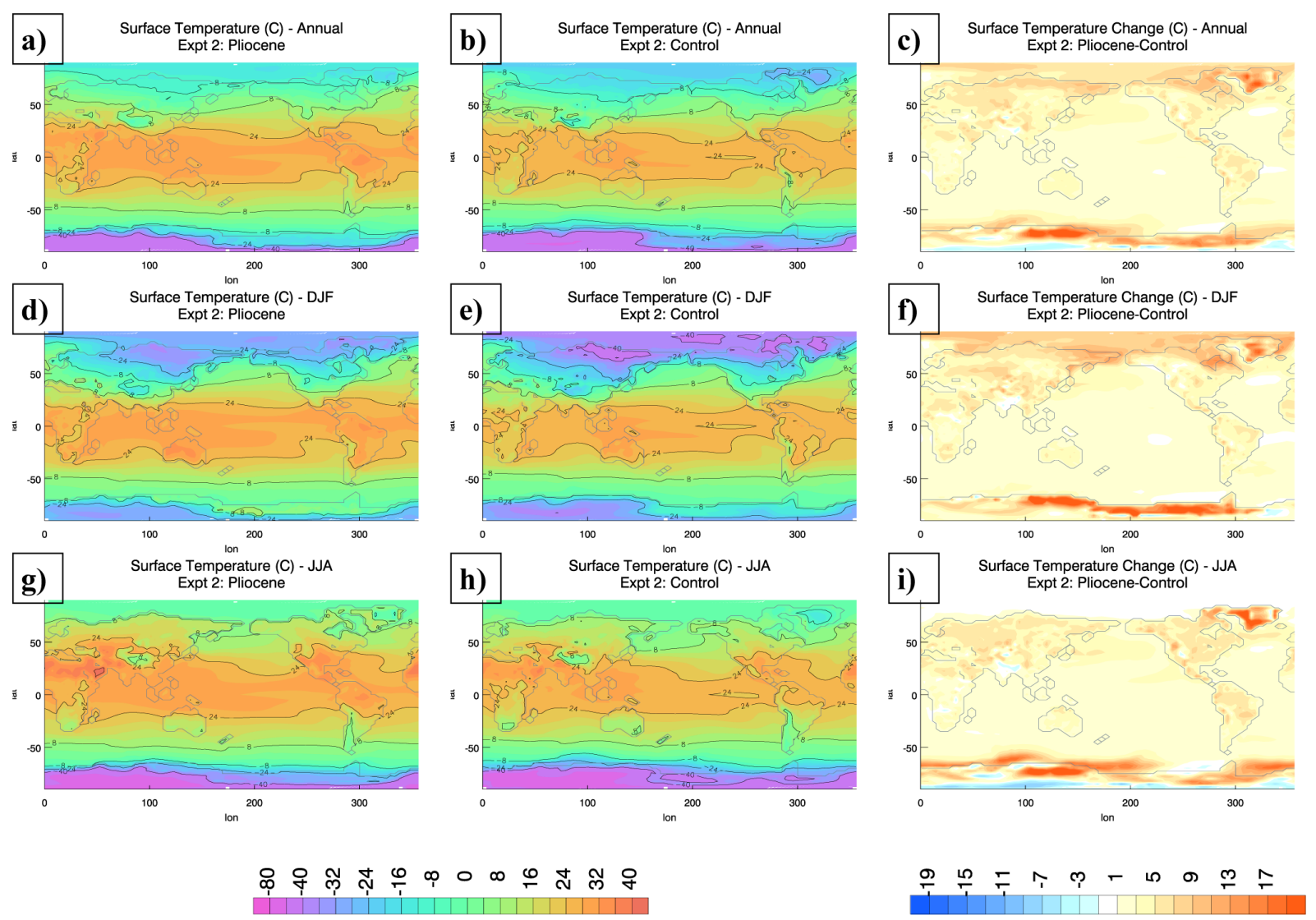

Fig. 8. Summary of surface air temperatures for Experiment 2: panels (a)-(c) show annual mean temperatures for Pliocene and control simulations and the difference between them. Panels (d)-(f) similarly show the DJF means and panels (g)-(i) the JJA means.

as Experiment 2 minus Experiment 1 differences in Pliocenecontrol changes in Fig. 12. Figure 12a-c again highlights the increased warming at lower latitudes and the reduction in polar warming in Experiment 2, especially apparent in the Northern Hemisphere. Taken together, the increased equatorial warming and reduced polar warming of Experiment 2 lead to an increased latitudinal temperature gradient, which is broadly similar in shape to that predicted for the control experiment (see Fig. 7a), in contrast to the reduction in latitudinal gradient shown by the PRISM reconstruction, implicit in Fig. 4c. Outside of the polar latitudes, there is a distinction between ocean and land warming in Experiment 2, typically close to $2{ }^{\circ} \mathrm{C}$ over water and $4{ }^{\circ} \mathrm{C}$ on land (see Figs. $7 \mathrm{e}, \mathrm{f}$ and $8 \mathrm{c})$.

This global shift in temperature is also apparent in greater spatial detail in Fig. 8, which shows global temperature patterns for Experiment 2. Outside of the polar regions, there is very little variation in temperature shift with latitude, only the marked difference between land and sea noted above. The difference in Experiment 1 and Experiment 2 patterns of temperature change are shown in Fig. 12d-f and confirm the previous observations, i.e. the equatorial ocean warms more in Experiment 2, the poles warm less, especially in winter and the land warms more than the oceans. The most striking difference is in the far north Atlantic which shows greatly reduced warming in Experiment 2 where the unconstrained ocean in the coupled simulation is not reproducing the "hotspot" in the PRISM3 sea surface temperature data which constrain Experiment 1.

Figure 9 shows precipitation patterns for Experiment 2. The Pliocene minus control differences for Experiment 2 are very different here from those seen for Experiment 1 in Fig. 6. In this case, there is an increase in equatorial precipitation and an intensification of the Indian monsoon. There is also a significant drying over equatorial South and Central America.

Figure 10 summarises the coupled model predicted sea surface temperatures and salinity for the Pliocene, control and the difference between them. Also shown are Atlantic (Fig. 11a and b) and Pacific (Fig. 11c and d) zonally averaged meridional overturning streamfunction. The change in sea surface temperature between the Pliocene and control broadly parallels that seen in surface air temperature over the oceans, a rise of the order of $2{ }^{\circ} \mathrm{C}$ in a fairly uniform distribution. There is a distinct change in circulation south of Greenland with adjacent warming and cooling zones. From 

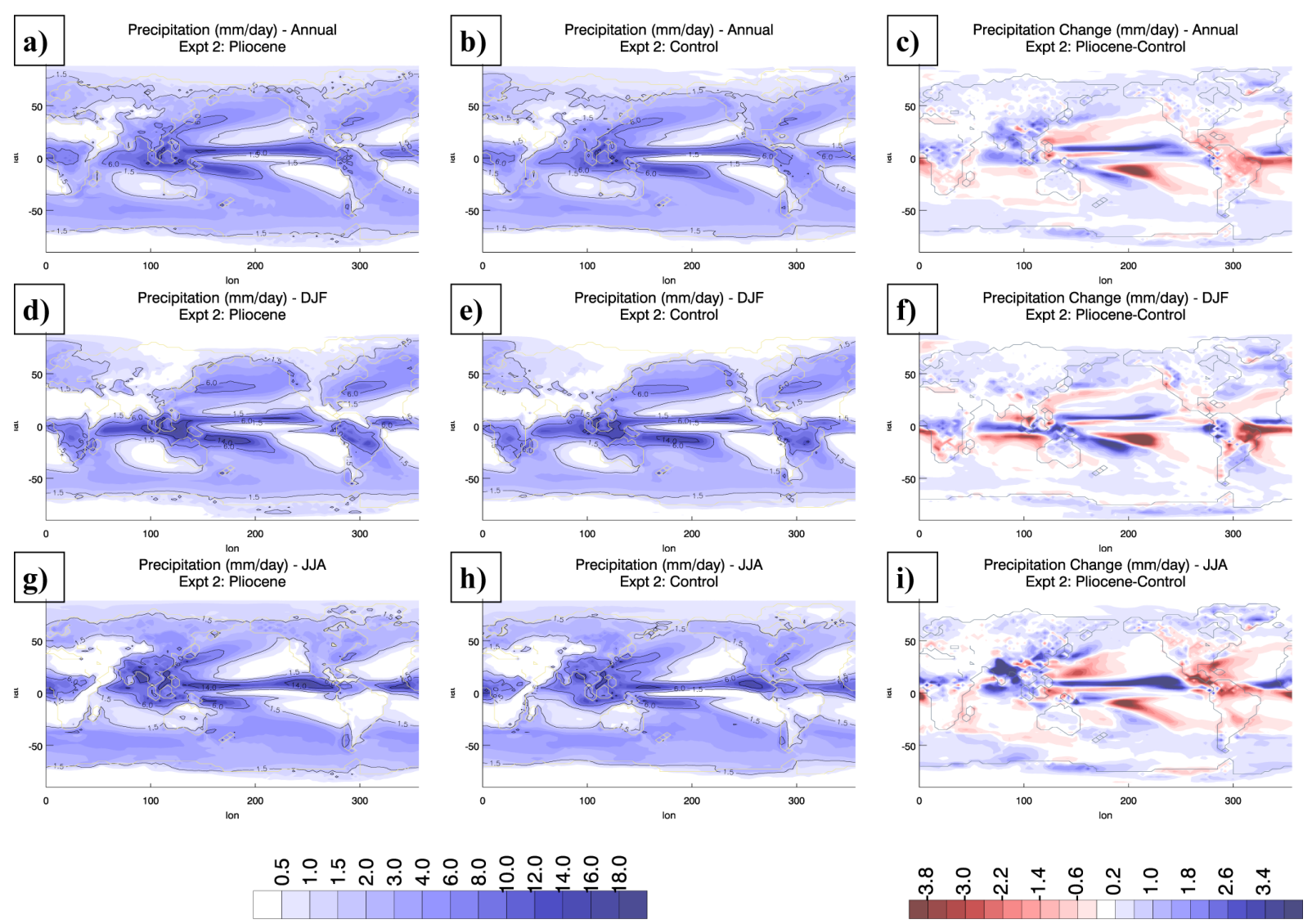

Fig. 9. Summary of mean precipitation $\left(\mathrm{mm} \mathrm{day}^{-1}\right)$ for Experiment 2: panels (a)-(c) show annual mean precipitation for Pliocene and control simulations and the difference between them. Panels (d)-(f) similarly show the DJF means and panels (g)-(i) the JJA means.

Fig. 11a and $\mathrm{b}$ it is apparent that the overturning circulation in the Pliocene North Atlantic is centred further south than in the control and that North Atlantic Deep Water formation is therefore occurring further south, consistent with the location of the cooling zone in Fig. 10c. Salinity increases in the Atlantic and is reduced in the rest of the world ocean, with the greatest decrease being in the Arctic ocean. The Pacific streamfunction shows a significant increase in the formation of Antarctic bottom water.

\section{Discussion}

\subsection{Comparison with data}

The model results are compared with data in Fig. 13. The Pliocene minus control sea surface temperatures from the coupled experiments are shown in the background contours. The data are shown as the difference between the PRISM3 confidence assessed Pliocene mean annual SST data points (Dowsett et al., 2012) and the annual mean of the Hadley Centre HadISST compilation of sea surface temperature observations (Rayner et al., 2003) averaged over the years 1870-1899 at the PRISM3 locations. Data sites along the
Eastern Pacific coast show high levels of warming over and above the general Pliocene increased warmth that are not reproduced by the model. Warming of the Kuroshio current off the East coast of Japan is present in the model. The relatively dense sampling of the North Atlantic shows consistent warming north of $50^{\circ} \mathrm{N}$. This extended "hotspot" is not reproduced by the model; however, there is a circulation change south of Greenland evident in the sea surface temperature change as discussed in Sect. 4.3. HadCM3 is known to be sensitive in the modern to the detailed submarine topography of the Greenland-Scotland Ridge in this region (Gordon et al., 2000) and recent work has also suggested that this region is sensitive to uncertainties in the Pliocene bathymetry (Robinson et al., 2011).

\subsection{Impact of revised PRISM3 boundary conditions}

The PRISM3 boundary conditions applied in the model are updated from the previous version, PRISM2 (Dowsett, 2007). Previous simulations have been carried out with the coupled model, using these older boundary conditions (Lunt et al., 2010) which we continued for $200 \mathrm{yr}$. Figure 14 shows the change in Pliocene-control differences for PRISM3 compared with PRISM2 boundary conditions (see Table 1 for 

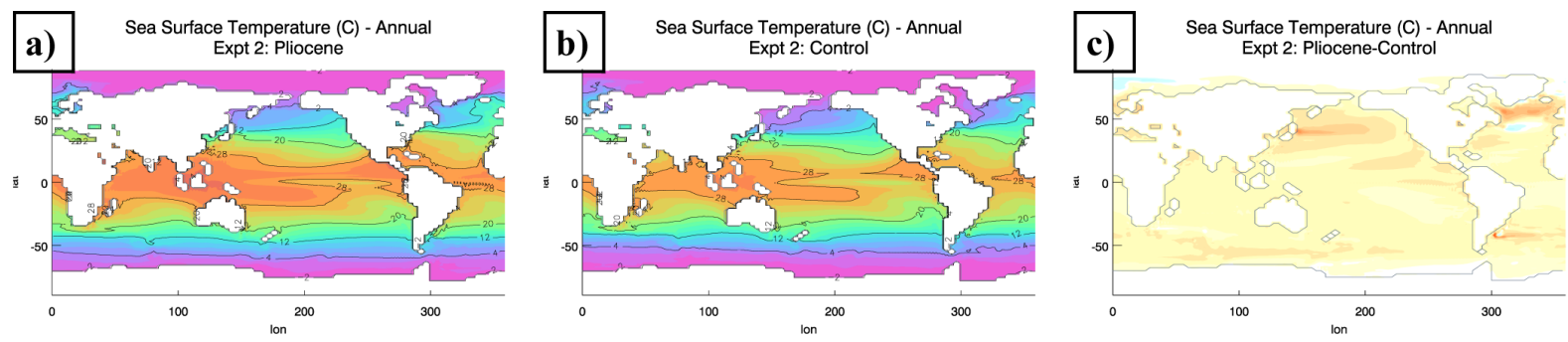

○Nナ
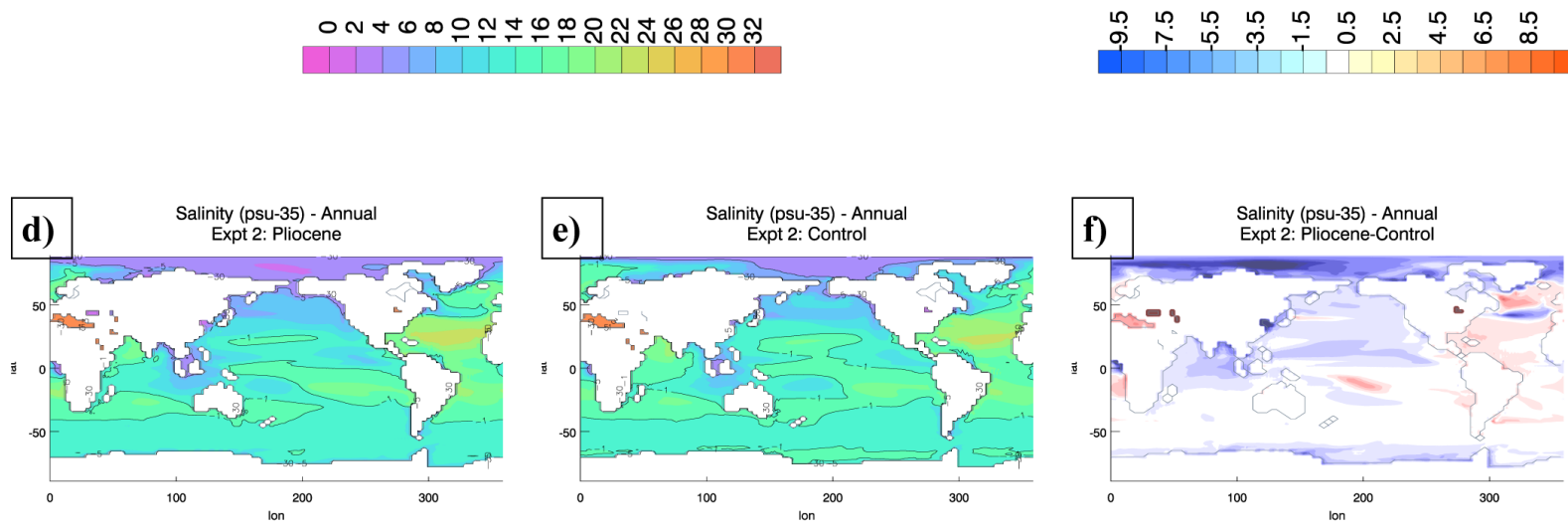

으은

Fig. 10. Summary of predicted ocean behaviour for Experiment 2: panels (a)-(c) show sea surface temperatures for Pliocene, control and the difference between them; panels (d)-(f) similarly show salinity.
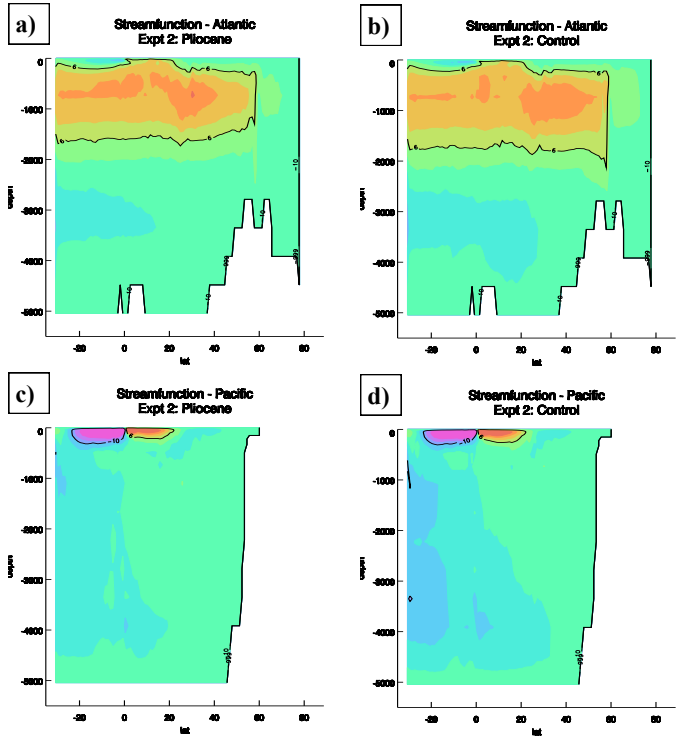

Fig. 11. Summary of predicted ocean behaviour for Experiment 2: Panels (a) and (b) show Atlantic overturning streamfunction for the Pliocene and control and (c) and (d) show the Pacific overturning streamfunction. details of the PRISM2 model simulation). There is very little difference in the simulations in terms of PRISM3PRISM2 global means: surface air temperature anomaly falls by $0.05^{\circ} \mathrm{C}$ and precipitation is unchanged to 3 significant figures. At the regional level, however, there is a distinct increase in seasonality of temperature over much of the land in the Northern Hemisphere. There are also temperature differences where ice sheet topography has been updated and in regions of significant change to the orographic boundary conditions, notably the Rockies which show cooling with PRISM3 topography even in summer when the rest of the Northern Hemisphere has a fairly uniform warming trend. Recent work has interrogated the impact of each set of boundary conditions $\left(\mathrm{CO}_{2}\right.$, orography, ice and vegetation) in the PRISM2 simulations (Lunt et al., 2012), and a similar study is required for the PRISM3 simulations in order to fully understand the changes shown in Fig. 14, but this result serves to highlight the significance of the uncertainty in boundary conditions on model predictions.

\subsection{Impact of alternative vegetation data in control experiment}

Here we examine the impact of using an alternate modern vegetation dataset in the Experiment 1 control simulation on the prediction of Pliocene - pre-industrial climate change. 

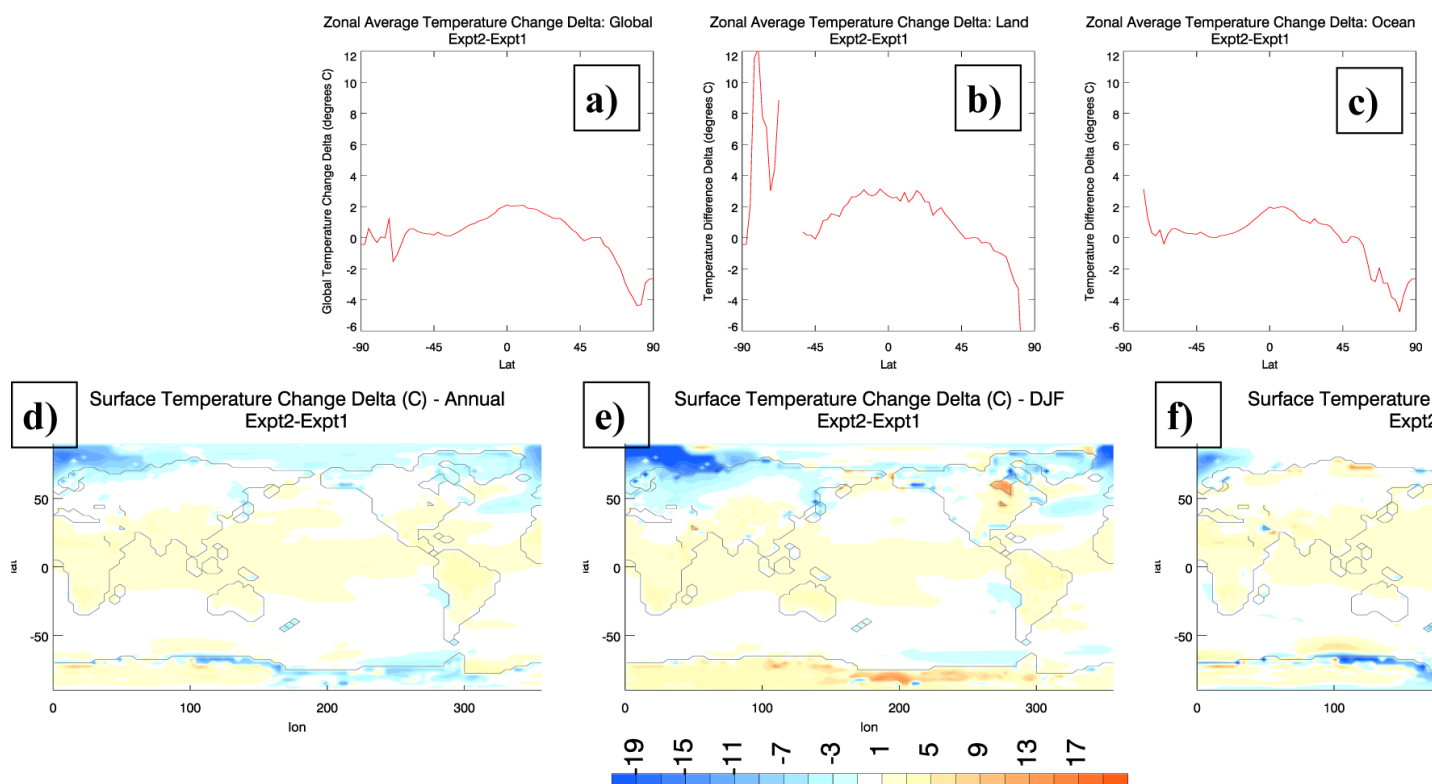

Surface Temperature Change Delta (C) - DJF
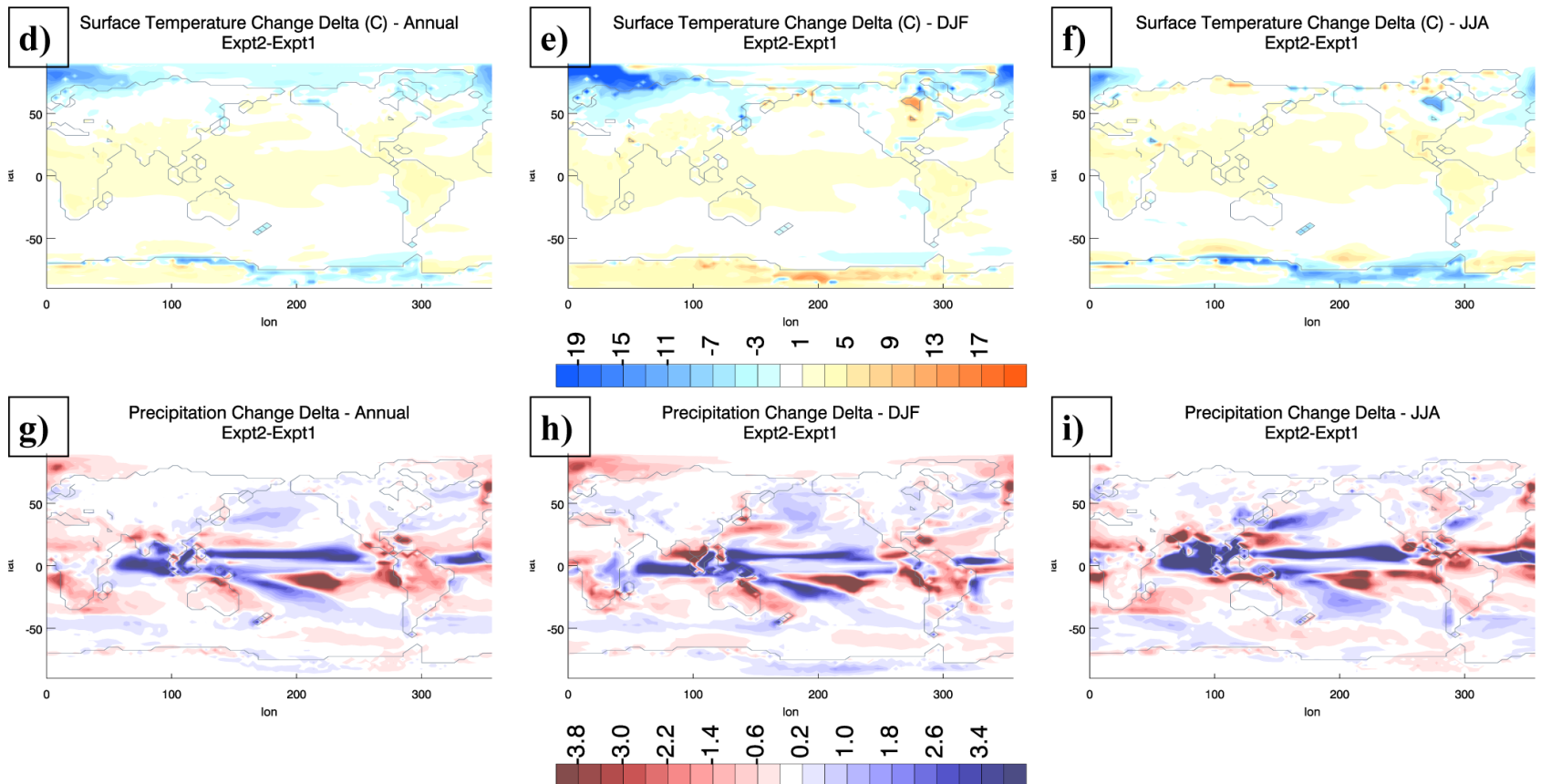

Fig. 12. "Difference of difference" showing the difference in Pliocene - control anomalies predicted by Experiments 1 and 2 . Differences are shown as Experiment 2 - Experiment 1. Panels (a)-(c) show zonal mean difference globally, for land only and ocean only. Panels (d)-(f) show surface air temperature change as annual mean, DJF mean and JJA mean. Panels (g)-(i) show precipitation change as annual mean, DJF mean and JJA mean.

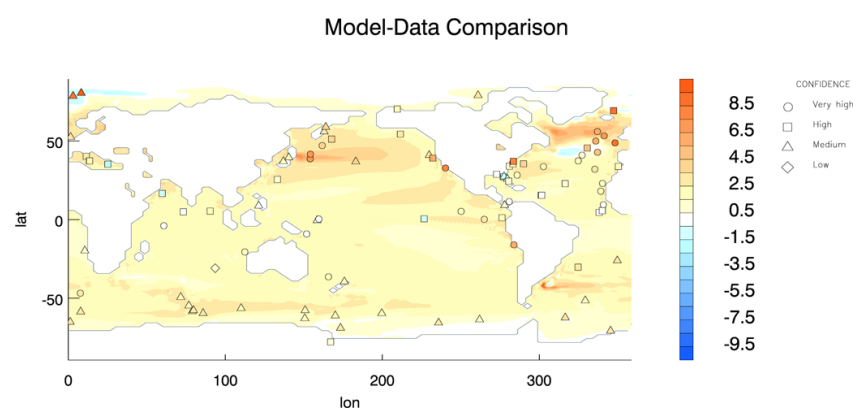

Fig. 13. Model data comparison. Background colour contours show Pliocene - control sea surface temperatures predicted for Experiment 2. Filled circles show PRISM3 - HadISST pre-industrial climatology annual means taken over 1870-1899. Symbol shapes show confidence level for each data point as assessed in Dowsett et al. (2012).
The control simulation for Experiment 1 used a standard pre-industrial vegetation dataset that includes the effects of human land-use change. PlioMIP also supplies an alternate modern biomes dataset designated here "BAS Modern" (BAS_Observ_BIOME.nc) whose data represent potential modern natural vegetation created by running the BIOME4 vegetation model (Haxeltine and Prentice, 1996, Kaplan et al., 2003) forced with a modern climate. The full setup for this experiment is listed in the "BAS Modern" column of Table 1. The same lookup process as for the Pliocene data was applied to derive surface characteristics from BIOME4 biomes (see Sect. 3.3). The differences in Pliocene-control climate change due to this change in the control simulation are shown in Fig. 15:

[Pliocene - BAS_Modern] - [Pliocene-Pre-Ind Control] $\equiv$ Pre-Ind Control - BAS_Modern. 


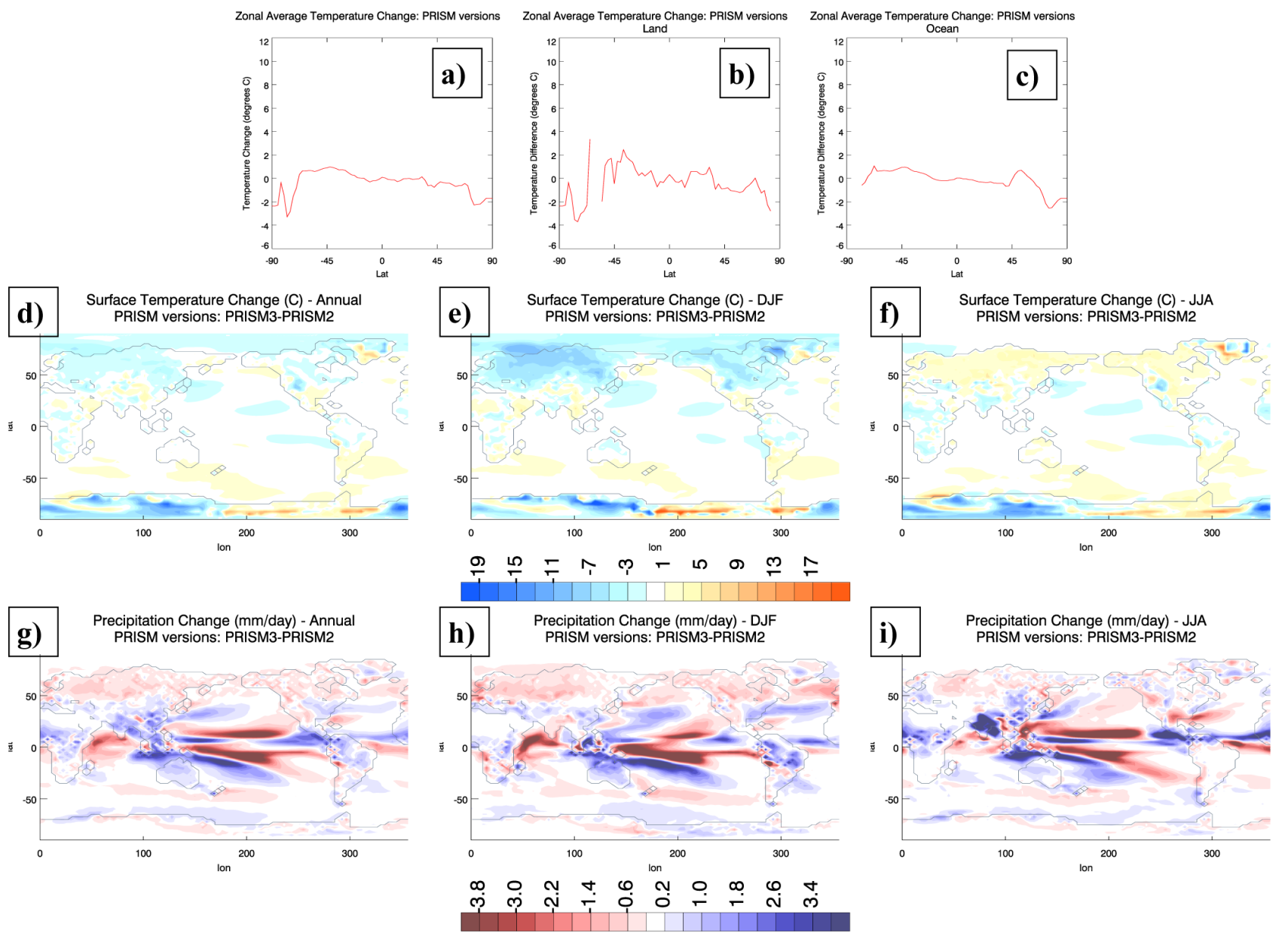

Fig. 14. "Difference of difference" showing the difference in Pliocene - control anomalies predicted using PRISM 3 and PRISM2 boundary conditions. Differences are shown as PRISM3 - PRISM2. Panels (a)-(c) show zonal mean difference globally, for land only and ocean only. Panels (d)-(f) show surface air temperature change as annual mean, DJF mean and JJA mean. Panels (g)-(i) show precipitation change as annual mean, DJF mean and JJA mean.

As with the change in Pliocene boundary conditions discussed above, this change in the control boundary conditions also results in significant changes to the predicted change in climate. The BAS_Modern simulation results in predicted temperatures around $2{ }^{\circ} \mathrm{C}$ higher than the standard pre-industrial control over much of the Northern Hemisphere land in Eurasia and North America, corresponding to a global annual mean temperature increase of $0.26^{\circ} \mathrm{C}$. This represents a reduction of around $10 \%$ in the total Pliocene - control warming relative to the standard experiment $(0.26$ in $2.5^{\circ} \mathrm{C}$ ). It is possible that the anomalies derived using the BAS_Modern control simulation are a closer representation of the true natural mid-Pliocene warming, as the vegetation changes include only naturally driven changes. Furthermore, the underlying biome vegetation types and their conversion to model boundary condition parameters is more consistent between the Pliocene and control simulations than in the standard pre-industrial control dataset.

\section{Conclusions}

- The predicted global mean temperature increase for the Pliocene is greater for the coupled model $\left(3.3^{\circ} \mathrm{C}\right)$ than the atmosphere-only version $\left(2.5^{\circ} \mathrm{C}\right)$.

- Polar amplification of $7{ }^{\circ} \mathrm{C}$ and $5^{\circ} \mathrm{C}$ in the northern and southern polar regions, respectively, is predicted in Experiment 1 , which is highly constrained by the PRISM3 SST dataset. In Experiment 2, lesser values of polar amplification of $3.5^{\circ} \mathrm{C}$ are predicted in both hemispheres, with higher equatorial warming thus giving a more even latitudinal distribution of warming.

- There is a marked difference in predicted precipitation patterns between the atmosphere-only and coupled models. The atmosphere-only model predicts reduced equatorial and Asian monsoon intensity, whereas in the coupled model these systems increase in intensity. 

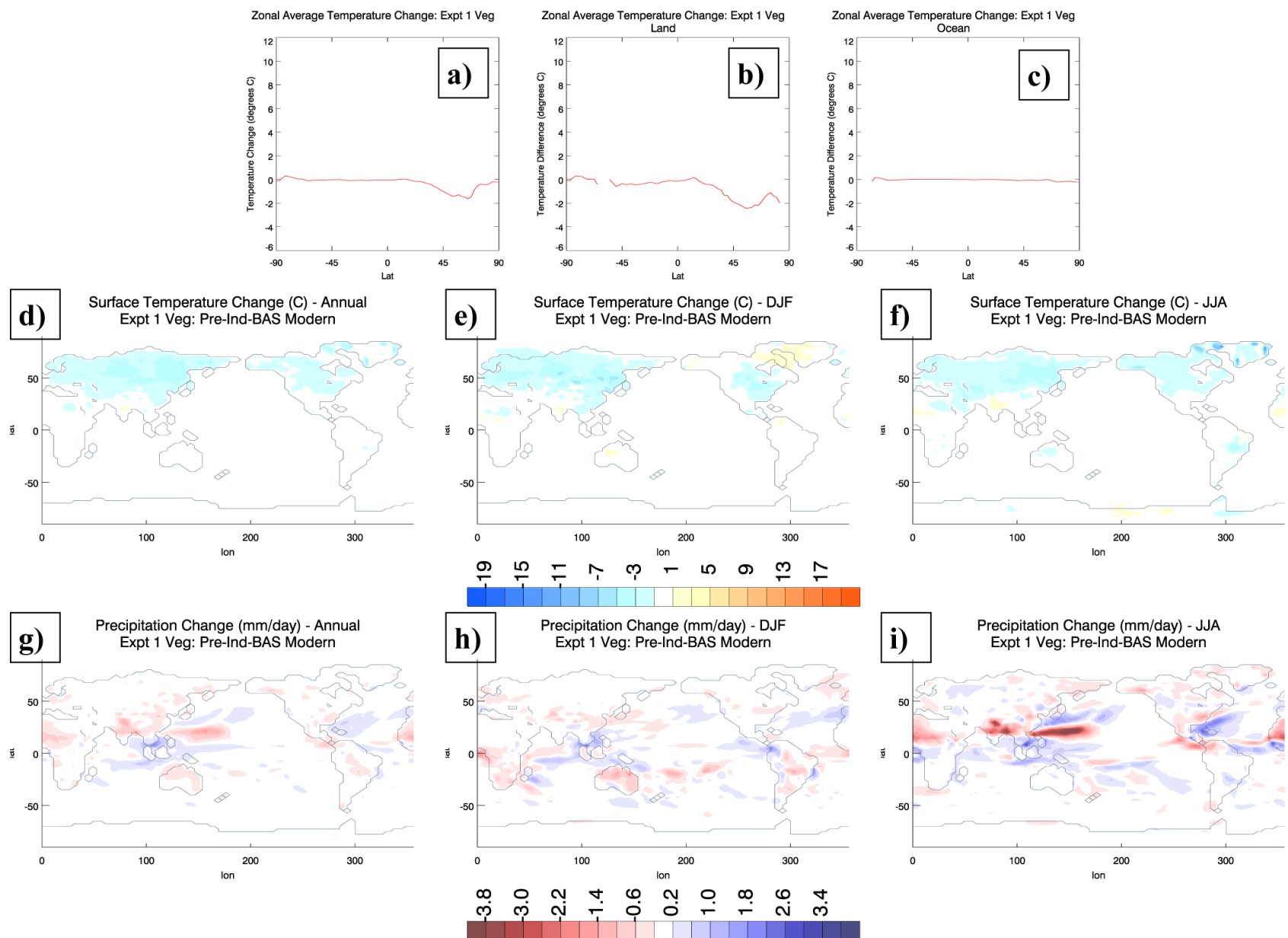

Fig. 15. "Difference of difference" showing the difference in Pliocene - control anomalies predicted using standard UM pre-industrial vegetation and using "BAS_Modern" vegetation to derive land surface properties. Differences are shown as: [Pliocene-BAS_Modern] [Pliocene-Pre-Ind Control] $\equiv$ Pre-Ind Control - BAS_Modern Panels (a) to (c) show zonal mean difference globally, for land only and ocean only. Panels (d) to (f) show surface air temperature change as annual mean, DJF mean and JJA mean. Panels (g) to (i) show precipitation change as annual mean, DJF mean and JJA mean.

- Features of the PRISM3 data that could be interpreted as suggesting changes in ocean circulation are partially supported by the coupled model results. There is good agreement in the region of the Kuroshio current which is predicted to warm significantly, but no evidence of Eastern Pacific coastal warming in present day cold upwelling zones. There is evidence of a distinct circulation change in the North Atlantic south of Greenland in the model consistent with a more southerly location for the formation of North Atlantic Deep Water in the Pliocene. In the data there is also a significant feature in the North Atlantic, but considerably further north.

- Sensitivity to boundary conditions was demonstrated using alternative datasets for both Pliocene and control simulations. Whilst the change from PRISM2 to PRISM3 mid-Pliocene conditions did not significantly alter the global mean climate, the change in control simulations from standard pre-industrial to potential natural modern vegetation reduced the predicted Pliocene minus control warming by $10 \%$.

Acknowledgements. The authors wish to acknowledge NERC grant (NE/G009112/1), which funded the AGCM simulations, NERC grant (NE/H006273/1) which funded F. J. B.'s PhD studies. A. M. H. acknowledges that the research leading to these results has received funding from the European Research Council under the European Union's Seventh Framework Programme (FP7/20072013)/ERC grant agreement no. 278636.

Edited by: J. Annan 


\section{References}

Arakawa, A. and Lamb, V. R.: Computational design of the basic dynamical processes of the UCLA general circulation model, in: Methods in Computational Physics Academic Press, eited by: Chang, J., New York, 173-265, 1977.

Cox, P. M., Betts, R. A., Bunton, C. B., Essery, R. L. H., Rowntree, P. R., and Smith, J.: The impact of new land surface physics on the GCM simulation of climate and climate sensitivity, Clim. Dynam., 15, 183-203, 1999.

Cusack, S., Slingo, A., Edwards, J. M., and Wild, M.: The radiative impact of a simple aerosol climatology on the Hadley Centre atmospheric GCM, Q. J. Roy. Meteorol. Soc., 124, 2517-2526, 1998.

Dowsett, H. J.: The PRISM palaeoclimate reconstruction and Pliocene sea-surface temperature, in: Deep-Time Perspectives on Climate Change: Marrying the Signal from Computer Models and Biological Proxies, edited by: Williams, M., Haywood, A. M., Gregory, F. J., and Schmidt, D. N., Bath, UK, Geological Soc Publishing House, 459-480, 2007.

Dowsett, H. J., Robinson, M., Haywood, A., Salzmann, U., Hill, D., Sohl, L., Chandler, M., Williams, M., Foley, K., and Stoll, D.: The PRISM3D paleoenvironmental reconstruction, Stratigraphy, 7, 123-139, 2010.

Dowsett, H. J., Robinson, M. M., Haywood, A. M., Hill, D. J., Dolan, A. M., Stoll, D. K., Chan, W. L., Abe-Ouchi, A., Chandler, M. A., Rosenbloom, N. A., Otto-Bliesner, B. L., Bragg, F. J., Lunt, D. J., Foley, K. M., and Riesselman, C. R.: Assessing confidence in Pliocene sea surface temperatures to evaluate predictive models, Nat. Climate Change, 2, 365-371, doi:10.1038/Nclimate1455, 2012.

Edwards, J. M. and Slingo, A.: Studies with a flexible new radiation code, 1. Choosing a configuration for a large-scale model, Q. J. Roy. Meteorol. Soc., 122, 689-719, 1996.

Edwards, M.: Global gridded elevation and bathymetry on 5-minute geographic grid (ETOPO5), NOAA, National Geophysical Data Center, Boulder, Colorado, USA, 1989.

Gent, P. R. and McWilliams, J. C.: Isopycnal Mixing in Ocean Circulation Models, J. Phys. Oceanogr., 20, 150-155, 1990.

Gordon, C., Cooper, C., Senior, C. A., Banks, H., Gregory, J. M., Johns, T. C., Mitchell, J. F. B., and Wood, R. A.: The simulation of SST, sea ice extents and ocean heat transports in a version of the Hadley Centre coupled model without flux adjustments, Clim. Dynam., 16, 147-168, 2000.

Gregory, D., Kershaw, R., and Inness, P. M.: Parametrization of momentum transport by convection, 2. Tests in single-column and general circulation models, Q. J. Roy. Meteorol. Soc., 123, 11531183, 1997.

Gregory, D., Shutts, G. J., and Mitchell, J. R.: A new gravity-wavedrag scheme incorporating anisotropic orography and low-level wave breaking: Impact upon the climate of the UK Meteorological Office Unified Model, Q. J. Roy. Meteorol. Soc., 124, 463493, 1998.

Haxeltine, A. and Prentice, I. C.: BIOME3: An equilibrium terrestrial biosphere model based on ecophysiological constraints, resource availability, and competition among plant functional types, Global Biogeochem. Cy., 10, 693-709, 1996.

Haywood, A. M., Dowsett, H. J., Otto-Bliesner, B., Chandler, M. A., Dolan, A. M., Hill, D. J., Lunt, D. J., Robinson, M. M., Rosenbloom, N., Salzmann, U., and Sohl, L. E.: Pliocene Model Inter- comparison Project (PlioMIP): experimental design and boundary conditions (Experiment 1), Geosci. Model Dev., 3, 227-242, doi:10.5194/gmd-3-227-2010, 2010.

Haywood, A. M., Dowsett, H. J., Robinson, M. M., Stoll, D. K., Dolan, A. M., Lunt, D. J., Otto-Bliesner, B., and Chandler, M. A.: Pliocene Model Intercomparison Project (PlioMIP): experimental design and boundary conditions (Experiment 2), Geosci. Model Dev., 4, 571-577, doi:10.5194/gmd-4-571-2011, 2011.

Hibler, W. D.: Dynamic thermodynamic sea ice model, J. Phys. Oceanogr., 9, 815-846, doi:10.1175/15200485(1979)009<0815:adtsim>2.0.co;2, 1979.

Ingram, W. J., Woodward, S., and Edwards, J.: UNIFIED MODEL DOCUMENTATION PAPER NO 23: RADIATION, Bracknell: Climate Research, Meteorological Office, London Road, Bracknell, Berkshire, RG12 2SY, United Kingdom, 1997.

Johns, T. C., Carnell, R. E., Crossley, J. F., Gregory, J. M., Mitchell, J. F. B., Senior, C. A., Tett, S. F. B., and Wood, R. A.: The second Hadley Centre coupled ocean-atmosphere GCM: Model description, spinup and validation, Clim. Dynam., 13, 103-134, 1997.

Kaplan, J. O., Bigelow, N. H., Prentice, I. C., Harrison, S. P., Bartlein, P. J., Christensen, T. R., Cramer, W., Matveyeva, N. V., McGuire, A. D., Murray, D. F., Razzhivin, V. Y., Smith, B., Walker, D. A., Anderson, P. M., Andreev, A. A., Brubaker, L. B., Edwards, M. E., and Lozhkin, A. V.: Climate change and Arctic ecosystems: 2. Modeling, paleodata-model comparisons, and future projections, J. Geophys. Res.-Atmos., 108, 8171, doi:10.1029/2002jd002559, 2003.

Kraus, E. B. and Turner, J. S.: A One-Dimensional Model of Seasonal Thermocline .2. General Theory and Its Consequences, Tellus, 19, 98-106, doi:10.1111/j.2153-3490.1967.tb01462.x, 1967.

Lunt, D. J., Haywood, A. M., Schmidt, G. A., Salzmann, U., Valdes, P. J., and Dowsett, H. J.: Earth system sensitivity inferred from Pliocene modelling and data, Nat. Geosci., 3, 60-64, doi:10.1038/Ngeo706, 2010.

Lunt, D. J., Haywood, A. M., Schmidt, G. A., Salzmann, U., Valdes, P. J., Dowsett, H. J., and Loptson, C. A.: On the causes of midPliocene warmth and polar amplification, Earth Planet. Sci. Lett., 321-322, 128-138, 2012.

Milton, S. F. and Wilson, C. A.: The impact of parameterized subgrid-scale orographic forcing on systematic errors in a global NWP model, Mon. Weather Rev., 124, 2023-2045, 1996.

NCAR/Navy: Global 10-minute elevation data, Digital tape available through National Oceanic and Atmospheric Administration, National Goephysical Data Center, Boulder, CO, 1984.

Pope, V. D., Gallani, M. L., Rowntree, P. R., and Stratton, R. A.: The impact of new physical parametrizations in the Hadley Centre climate model: HadAM3, Clim. Dynam., 16, 123-146, 2000.

Rayner, N. A., Parker, D. E., Horton, E. B., Folland, C. K., Alexander, L. V., Rowell, D. P., Kent, E. C., and Kaplan, A.: Global analyses of sea surface temperature, sea ice, and night marine air temperature since the late nineteenth century, J. Geophys. Res.Atmos., 108, 4407, doi:10.1029/2002jd002670, 2003.

Robinson, M. M., Valdes, P. J., Haywood, A. M., Dowsett, H. J., Hill, D. J., and Jones, S. M.: Bathymetric controls on Pliocene North Atlantic and Arctic sea surface temperature and deepwater production, Palaeogeogr. Palaeoclimatol., 309, 92-97, doi:10.1016/j.palaeo.2011.01.004, 2011. 
Smith, R. N. B.: A Scheme for Predicting Layer Clouds and Their Water-Content in a General-Circulation Model, Q. J. Roy. Meteorol. Soc., 116, 435-460, 1990.
Wilson, M. F. and Henderson-Sellers, A.: A Global Archive of Land Cover and Soils Data for Use in General-Circulation Climate Models, J. Climatol., 5, 119-143, 1985. 